example of the majority in the commonwealth of British nations, Great Britain will be left as the only country in the world where the spelling "felspar" still remains. Commercial men must be well acquainted with the correct form; they are, moreover, not going to be asked to use the German form " feldspat," any more than " kainit," which has become common without a final " e." The spelling " feldspar" of course carries with it "feldspathic" and "feldspathoid"; also "feldstone" for "felstone," a term that might well be abandoned. "Felsite" remains unaltered.

Carrickmines, Co. Dublin, Grenville A. J. Cole. January ro.

\section{Standardisation of Scientific and Technical Publications.}

IN reply to Mr. W. P. Widdowson's letter in NATURE of January I2, p. 5I, I should describe as very unsafe his supposition that a standard page size would be rather futile unless nearly every publication adopted it. There are many possible uses of a standard size, and some of them have little connexion with the general body of scientific literature. In my communication to NATURE of December r, p. 794, I did not perhaps sufficiently indicate that what I have in mind is a series of proposals to suit different sets of circumstances rather than any rigid scheme. I am now writing an account in which I am distinguishing between those proposals which I suggest are immediately practicable, and those which lie rather in the future.

2o Watery Lane, Merton Park, London, S.W.2o.

\section{The Hypothetical North Polar Land.}

IT has often been suggested that land exists to the north of Alaska, and the extent of American confidence may be gauged by the proposal to send the airship Shenandoah to annex " the vast unexplored areas contiguous to Alaska" for the U.S.A. R. A. Harris deduced the existence of this land from tidal observations in the Arctic Ocean, and marked its approximate boundaries on a map of co-tidal lines for the Arctic regions (Arctic Tides, U.S. Coast and Geodetic Survey, I9II).

Further evidence is now to hand which throws doubt upon this hypothesis. The Maud has been drifting in the ice north of Siberia for some years, and regular tidal observations were carried out at her winter quarters at Maud Harbour (1918-19), Aion (I9I9-20), and Cape Serdze Kamen (I920-2I). These observations have been sent to the Geophysical Institute at Bergen, and J. E. Fjeldstad has published a preliminary note on the result of his examination of the material (Naturen, I923, p. I6I).

Fjeldstad comes to the conclusion that the existence of any such land area as Harris postulates is unlikely, although it is admitted that the ocean to the north of the Beaufort Sea may be relatively shallow and dotted with islands. A new co-tidal map is given, in which all known observations are interpreted on the hypothesis of a wave which enters the Arctic Ocean between Spitsbergen and Greenland and reaches the northern shores of Siberia and western North America by direct paths across an unrestricted polar sea. Even if the Shenandoah is able to make a successful flight, the annexation of territory may not be so considerable as is hoped for.

L. HAWKES.

Bedford College,

Regent's Park, N.W.I,

January $2 \mathrm{r}$.

NO. 2834 , VOL. I I 3 ]
Chemotaxis of Spermatozoa and its Questioned Occurrence in the Animal Kingdom.

IN an interesting paper in the British Journal of Experimental Biology for January, Prof. Dakin and Dr. Fordham have shown that capillary tubes which contain sea water which has been in contact with the ripe eggs of Echinus esculentus soon become plugged with spermatozoa after immersion in sperm solution. This result is contrary to that obtained by Buller and Loeb, and appears to prove that chemotaxis is a factor in the fertilisation of Echinus, as claimed already by de Meyer.

Prof. Dakin and Dr. Fordham do not, however, refer to my earlier demonstration of chemotaxis in sponge fertilisation. In 1920 I showed that the oocytes of Grantia lie beneath the collar cells, and that the spermatozoa carried in by the inhalent currents are definitely attracted to the collar cell region overlying the eggs. This was the first " natural " demonstration of chemotaxis made on animal material (Jour. Linn. Soc., vol. xxxiv., Nov. I920, p. 280).

In the case of the fertilisation of the mammal, where ovarian pregnancies occur, it is difficult to believe that the egg does not exert some attraction for the wandering spermatozoon.

In Saccocirrus, where precocious fertilisation is the rule, it is obvious that the ovary must be a goal towards which the spermatozoa swim, because sperms do not occur, to my knowledge, in any part of the segment excepting the ovaries and receptacles.

A possible explanation of de Meyer's and Dakin's success where Buller and Loeb failed is that the former obtained the eggs at just the right period.

There never has been any doubt in my mind that chemotaxis is a factor in animal fertilisation, and I consider that the observations of de Meyer and the Liverpool workers and my own researches on Grantia place the matter altogether in a new light.

Zoological Department,

Trinity College, Dublin, February 4.

The Thermal Expansion of Bismuth Grystals.

In order to provide data which shall form a basis for a theory of non-cubic metallic crystals, Grüneisen and Goens have carried out experiments on the thermal expansion from $-180^{\circ} \mathrm{C}$. to $100^{\circ} \mathrm{C}$. and on other properties of single crystals of zinc and cadmium, the results of which were published in the Physikalische Zeitschrift for December 15, 1923. They mention that crystals of bismuth and antimony have not yet been studied. For some time I have been engaged on an investigation of the thermal expansion of bismuth crystals from ordinary temperatures up to the melting-point $269^{\circ} \mathrm{C}$. The experiments above $220^{\circ} \mathrm{C}$. are not yet quite complete, but the results obtained up to this temperature indicate that the behaviour of bismuth crystals is different from that of the metals examined by Grüneisen and Goens. In the case of bismuth the expansion in either direction, i.e. parallel or perpendicular to the axis, is practicallv uniform over this wide range. The results of Grüneisen and Goens show a considerable variation in both expansion coefficients in the range $0^{\circ}$ to $70^{\circ} \mathrm{C}$. for cadmium crystals, and in the expansion coefficient perpendicular to the axis for zinc crystals. It is hoped that full details of these experiments will be published shortly.

National Physical Laboratory Teddington, Middlesex, February 5 .
J. Keith Roberts. 